Richard I. Hall MD FRCPC FCCP, Patrick J. Duncan QC, Graeme Rocker MA DM FRCP FRCPC

\section{Death in the ICU - the Halifax experience}

and nurses were given a set of orders and asked to indicate the amount of drug they would administer based on the set of medication orders received. There was a 10 -fold difference in dose range ordered by physicians. The dose range chosen for morphine which could be given by nursing is shown in Figure 1. Within the constraints of choices based on a single case scenario, there is substantial variability in the amount of drug which might be administered depending on which physician and/or nurse was at the bedside at the time withdrawal of life support occurred.

\section{What do ICU practitioners actually do? ${ }^{23}$}

We have performed an in-depth analysis of end of life care in the ICU over one year. In that time, 1,327 patients were admitted to the ICUs. There were 1,153 survivors discharged alive from the ICU (87\%). In 138 patients (10.4\%) decisions were made to withdraw/withhold life support, and a further 36 patients $(2.7 \%)$ died despite continued active treatment.

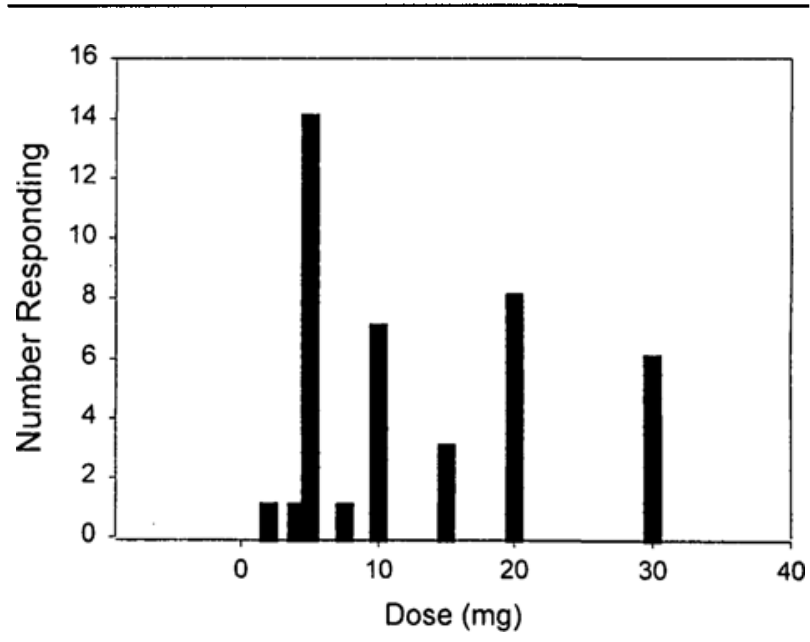

FIGURE 1 Variability in morphine administration over $30 \mathrm{~min}$ among nurses given a hypothetical set of orders involving withdrawal of life support in a patient in the ICU.

Richard I. Hall MD FRCPC FCCP, Professor of Anesthesia, Associate Professor of Pharmacology and Surgery, Dalhousie University; Medical Director, Intensive Care Services, Queen Elizabeth II Health Sciences Centre, Halifax, Nova Scotia

Patrick J. Duncan QC, Beveridge, Lambert \& Duncan, Barristers \& Solicitors, Halifax, Nova Scotia

Graeme Rocker MA DM FRCP PRCPC, Associate Professor of Medicine, Dalhousie University; Medical Director, Medical/Surgical Intensive

Care Unit, VG Site, Queen Elizabeth II Health Sciences Centre, Halifax, Nova Scotia 
Death related to withholding or withdrawal of life support thus occurred in $79.3 \%$ of non-survivors. The median hourly dose of morphine and lorazepam for the final $\mathbf{1 2} \mathrm{hr}$ of life was $\mathbf{5}$-fold higher in patients in whom life support was withdrawn than in patients in whom it was not. Again, there was considerable variability among physicians in dosing of medications for comfort care ( $>10$-fold). There are other reports of medication use at the end of life in the ICU which show some similarities to our data. For example, reported doses of morphine administered during the withdrawal of life support range from 0 to $350 \mathrm{mg} \cdot \mathrm{hr}^{-1}{ }^{16,21}$ with an increase from $5.7 \pm$ $1.7 \mathrm{mg} \cdot \mathrm{hr}^{-1}$ prior to withdrawal to $14.8 \pm 4.5 \mathrm{mg} \cdot \mathrm{hr}^{-1}$ during withdrawal. ${ }^{19}$ It would be reasonable to question why there is so much variability in drug dosing during the withdrawal of life support process.

Physicians practising palliative care in the ICU during withdrawal of life support may administer substantial doses of medication (usually opioids and sedatives) to ensure patient comfort. This has been a well accepted ethical practice and is based on the principle of 'double effect'. In essence, this principle allows the administration of medication designed to promote a patient's comfort during the dying process with the understanding, however, that side effects such as respiratory depression (which may hasten the patient's death from his or her underlying disease) are acceptable, providing the physician's intent was to promote patient comfort. Under this principle, no upper limit of drug dosing is required and application of the principle in practice may explain some of the variability in medication use observed among physicians and other care- givers involved in end of life care. Our experience, on the other hand, suggests that justification of medication changes should be based only on objective measures of pain, dyspnea, or discomfort and that defined upper limits of medication dosage be reviewed regularly as the dying process proceeds. Medication which does not provide direct patient comfort e.g. neuromuscular blocking agents and potassium chloride are likely to be problematic if used in association with ending 'suffering', no matter how well intentioned the physician. Until Canadian law clarifies this issue, we cannot recommend such practice. Our physician was charged with first degree murder under the Criminal Code of Canada. Section 23l(2) of the Criminal Code of Canada ${ }^{a}$ (C.C.C.), when read in conjunction with s.229 C.C.C., sets out the essential elements of a first degree murder charge as follows:

\section{1. "... where a person who causes the death of a buman being \\ i) means to cause his death; or \\ ii) means to cause bim bodily harm that be knows}

is likely to cause death and is reckless as to whether death ensues or not; ${ }^{26}$

2. And that the murder was "planned and deliberate".c

Depending on one's interpretation of these clauses, nearly all cases of life support withdrawal could be questioned regardless of the drug employed and it is, therefore, imperative for physicians to record all discussions with patients/families and to document their intent and process carefully.

The following sections address the consequences of such a charge for both individuals and institutions.

\section{Unusual events and professional responses}

It may seem surprising that when a physician encounters a situation involving the death of a patient under unusual circumstances, in some provinces, including Nova Scotia at the time of writing, there is no duty to report these cases to authorities outside the hospital. Alberta, in $\mathbf{s . 1 0}$ of the Fatality Inquiries Act ${ }^{\mathrm{d}}$ requires immediate notification to a medical examiner or an investigator by any person having knowledge or reason to believe that a person has died under a variety of circumstances which include, inter alia, "unexplained deaths", "deaths that may have occurred as a result of improper or negligent treatment by any person"; deaths during or shortly after operative procedures and deaths that are the result of poisoning. British Columbia, in the Coroners' Act, ${ }^{e}$ has a similar requirement to report to a Coroner or a peace officer the "facts and circumstances relating to a death" by a person who has reason to believe that the death was as a result of, inter alia, "negligence, misconduct, malpractice" or from any cause, other than disease, under circumstances that may require investigation. $(s e e, s .9)^{\mathrm{f}}$ New Brunswick's Coroners' Act, in s.4, has a provision similar to that of British Columbia.

At the QEII HSC, as a consequence of the internal Hospital investigation, the physician's privileges were changed but the Hospital did not report the case to the family, the Medical Advisory Committee, the Hospital Board of Directors, the Medical Examiner, or the College of Physicians and Surgeons of Nova Scotia. In the subsequent report of the external review team chaired by Dr. Charles Wright, it was stated that "the steps taken, inappropriate as they were, were taken

\footnotetext{
a Criminal Code of Canada R.S.C. 1985, c.C-46, as amended

b s.229(a) (i); 229(a)ii) Criminal Code of Canada

's.231 (2) C.C.C.

${ }^{d}$ RS.A. 1980, c.F-6, as amended

' R.S.B.C. 1996, C.72, as amended

i R.S.N.B. c.C-23, as amended
} 
in a misguided attempt to protect a colleague from potentially serious consequences arising out of an apparent act of compassion, and to protect the hospital from adverse publicity." This response may have influenced the police conduct in the subsequent search and seizure conducted at the Hospital. The police investigators apparently inferred that, as a result of non-disclosure, the Hospital and its staff were actively engaged in a cover-up necessitating, in police minds, a highly intrusive unannounced search. The Wright report went on to recommend that 'Beyond the constraints of patient confidentiality and legally protected information, full disclosure of extraordinary events and institutional processes is in the best interests of the institution and public.' One may wonder whether the charged atmosphere, in the absence of open discussion, contributed to the laying of a charge which was far more serious than had been laid in some similar circumstances e.g. administering a noxious substance contrary to s. 245 C.C.C. In our own case, the subsequent damage to individuals involved, to reputations including those of the institution and its leaders, loss of public trust in the institution and its ability to deliver care to its constituents, damage to the morale of care-givers within the ICU, costs of identifying what went wrong, by whom, and the development of processes to rectify the problems identified have been huge. We recommend that institutions and their leaders carefully consider the impact of their decisions when weighing the best interests of individuals or of the institution as a whole.

As a result of its review of the Hospital's handling of the investigation, Dr. Wright's Committee made several recommendations including more open disclosure of extraordinary events, amendments to the Medical Act of Nova Scotia to require mandatory notification in situations where physician privileges are revoked for more than two weeks, a change in the Fatality Inquiries Act to make it mandatory to report to the Medical Examiner any suspicious or unusual deaths, changes in Hospital bylaws for reporting unusual circumstances, and an increased effort to educate the public and profession surrounding end of life care.

Of the above recommendations, efforts to ensure full disclosure of unusual events at the Hospital continue, Hospital bylaws are under revision, and public/professional education is ongoing. Letters have been written on behalf of the QEII HSC to relevant authorities to request statutory amendment. However, no changes in law have yet occurred. Better definition is required concerning acceptable care at the end of life and to distinguish between acts of compassion and those of maleficence and to provide guid- ance as to the timing and nature of any necessary reporting and to whom.

\section{Legal issues}

Our experience of events at the QEII HSC has increased our understanding of legal processes although not under circumstances of our choosing. To educate other physicians who may unwittingly also find themselves in unfortunate legal circumstances, what follows addresses some aspects of the law with which we believe physicians should become familiar.

\section{The differences between civil and criminal lawsuits}

The major differences include the nature of the parties involved and the purpose of the proceedings. Civil law suits are private actions taken by one party, the Plaintiff, against another, the Defendant, with the purpose of achieving redress for an alleged injury or wrongdoing and with the intent to recover monetary damages incurred as a result of perceived injury. As such, evidence put before the Court addresses the Defendant's liability and the quantum of damage arising therefrom. While there are powers to compel production of relevant documents and some ability to compel attendance for evidence in Discovery hearings, there are some restrictions placed on access to the documents of opposing parties and their advisors, as well as those of third parties which are not present in the criminal process.

In Criminal law, when police investigators are made aware of possible wrong-doing, they have an obligation to conduct a thorough investigation and, if at the conclusion of that investigation they have reasonable and probable grounds to conclude that an offence has been committed, then to lay a charge (called an Information) before the appropriate Court of criminal jurisdiction. During this investigative process the police have broad powers of search and seizure which generally must be pre-authorized by a Justice of the Peace or a Judge issuing a Search Warrant.

Hospital processes, including peer reviewed activities and private files, which may be exempt from scrutiny in a Civil law suit, are available for scizure and review by police investigators in a criminal process. Those documents may later become available in a public forum. There is no doctor-patient privilege in criminal cases. In the criminal process, solicitor/client privilege is one of the few that is recognized as being capable of keeping seized documents from public scrutiny. The law remains unclear concerning privilege in the peer review process.

Once a charge is laid, the Crown Attorney must review the information put before him/her to deter- 
Queen Elizabeth II Health Sciences Centre

\section{WITHDRAWAL OF LIFE SUPPORT CHECKLIST}

1. Does the patient have a living will or a durable Power of Attorney for health issues? $\square$ Yes

If YES, is the proposed decision to withdraw life support in accordance with the wishes expressed in the living will or the durable Power of Attorney? $\begin{array}{ll}\text { Copy on the chart } & \square \text { Yes }\end{array}$

2. Has the referring Doctor been notified? Service

3. Has the second staff physician's opinion re: withdrawal of life support been obtained?

4. If the patient is competent, has he/she been involved in the decision making process?

5. If the patient is not competent or unconscious, has the next-of-kin/substitute decision maker been involved in the decision making process?

6. Has the ICU doctor communicated the plan of care to the family? If NO, why? e.g. unable to reach

$\square$ Yes

$\square$ Not required

$\square$ Yes

口 Yes

$\square$ Incompetent

$\square$ Yes

$\square$ No

7. Has the discussion been documented on the chart by: PHYSICIAN

NURSE

8. Has the DO NOT RESUSCITATE ORDER been written?

9. Has the patient and/or family had the opportunity to speak to a spiritual resource person?

10. Are there any particular religious/cultural practices to be followed at the time of death? List

11. Where appropriate, have other consulting support services been notified? Service

12. Have COMFORT MEASURES been implemented?

13. Has all other active treatment been withdrawn? $\square$ Yes

$\square$ No

Yes

When

$\square$ Yes

$\square$ Declined

$\square$ Yes

$\square$ No

$\square$ Yes

$\square$ Not required

$\square$ Yes

口Yes
PHYSICIAN'S SIGNATURE
NURSE'S SIGNATURE

\section{DATE}

YYY/MM/DD

FIGURE 2

mine whether or not the prosecution should continue on the charge laid, on some other charge, or at all. Provinces have different tests that Crown Attorneys must apply in determining whether to terminate a prosecution commenced by the police.

\section{Your rights and what to do when confronted with a criminal investigation}

In a criminal investigation, you may be interviewed by the police. From personal experience, this can be very intimidating. The first contact with the police in the Halifax investigation occurred when they entered the offices of the Intensive Care physicians to look through all personal files, computer files, etc. The police were well informed, knew what questions to ask and where to look for relevant documents. This was followed by questioning of each of the physicians regarding their role in the matter. No information was given regarding the right to legal representation and 'statements' were recorded without a lawyer present for those physicians who did not insist on the presence of legal counsel. No option to contact a lawyer was provided but rather the impression was given that, unless there was full cooperation, the possibility existed that the physician would be considered an accessory to the "crime". With hindsight, the lesson learned 
is that the presence of a lawyer ensures your protection and you should not give statements, even though you have nothing to hide, without legal advice, however intimidating the questioning of this appears. Without this advice, you could make statements under stress, later regretted.

When first contacted by the police, it is important to determine whether the police wish to speak with you as a witness or as a suspect. In either case, you should ask to consult legal counsel before providing a statement or participating in an interview. If you are a suspect, you have an absolute right to contact counsel and should do so before saying anything to the police. If you are a witness, the police are under no legal obligation to advise you that you may speak with counsel before being questioned. Generally speaking, the witness is under no obligation to speak to the police and delaying an interview until you have had an opportunity to consult counsel would be entirely justifiable and appropriate.

If the police arrive at your office with a Search Warrant, they are required to give you a copy of that Warrant which needs to specify date, time, place, and what they are looking for. The Search Warrant should be carefully reviewed in this light. If they do not give you a copy of the Search Warrant, you should request that you be provided with one. If the police have a Search Warrant, then they have the right to search your office and seize anything which falls under the Search Warrant. If the police do not have a Search Warrant, then they have no right to search your office and you may be breaching your duty of confidentiality to your patient if you consent to such a search in the absence of a Search Warrant. Without a Search Warrant, you can demand that they leave your office. Once you have made your objections clear, if the police continue with the search, their conduct will be subject to judicial and/or disciplinary review upon complaint.

If you are served with a Subpoena to attend Court, you should consult counsel to ensure that the Subpoena is valid and that you have relevant evidence to give. There is a procedure by which your lawyer, in some circumstances, could apply to quash the Subpoena. If the Subpoena is not quashed then you must attend Court as it requires.

\section{Processes in place as a result of this experience}

We have examined our processes surrounding end of life care in the ICU. In particular, we have examined the provision of sedation and analgesia in general to ICU patients and have developed an evidence-based sedation algorithm to manage this aspect of care. We have adopted a pain/sedation/dyspnea assessment tool to allow us to identify and thus effectively manage adverse symptoms. We have abandoned the use of "open-ended orders" for sedation and analgesia during the withdrawal of life support process. We require our attending physicians to be much more involved in family discussions and the process of end of life care. We have put in place a Withdrawal of Life Support checklist to ensure we no longer overlook missed or inadequately addressed issues determined by our satisfaction surveys e.g. religious/spiritual concerns (Figure 2). We have appointed a Palliative Care physician as an honorary member of our ICU group and we seek much more interaction between Palliative Care and Intensive Care than we did previously. We are in the process of developing a Do Not Resuscitate (DNR) checklist. These measures have allowed us to improve upon the standardization of care and upon documentation during the process of withdrawal of life support.

\section{Conclusions}

From the perspective of process, be careful what is said during procedures involving disciplinary actions and what is written afterwards. The Minutes of any such meetings should be scrutinized for accuracy and corrected as needed. It is always wise to consider how the documentation would appear if printed on the front page of a national newspaper or broadcast on the radio or television. In any criminal case, the likelihood of such documents being used as evidence and subsequently becoming public knowledge is real. Regarding end of life care in the ICU, there is a clear need for dialogue. Physicians would do well to educate themselves about end of life care and to become involved in efforts to increase public awareness of the issues. Given the variability of care demonstrated during the withdrawal of life support process, our admission of an increasingly elderly and sick patient population, and the lack of appropriate dialogue at Federal and Provincial levels concerning modification of the current statutes, the likelihood of further legal actions (both civil and criminal) against physicians is unfortunately very real. We believe it is time for professional organizations such as the Canadian Anesthesiologists' Society (CAS) to become more involved in these issues both from an educational and political perspective.

\section{References}

I Prendergast TJ, Luce JM. Increasing incidence of withholding and withdrawal of life support from the critically ill. Am J Resp Crit Care Med 1997; 155: 15-20.

2 Prendergast TJ, Claessens MT, Luce JM. A national sur- 
vey of end-of-life care for critically ill patients. Am J Resp Crit Care Med 1998; 158: 1163-7.

3 Gilligan T, Raffin TA. Withdrawing life support: extubation and prolonged terminal weans are inappropriate (Editorial). Crit Care Med 1996; 24: 352-3.

4 Asch DA, Hansen-Flaschen J, Lanken PN. Decisions to limit or continue life-sustaining treatment by critical care physicians in the United States: conflicts between physicians' practices and parients' wishes. Am J Resp Crit Care Med 1995; 151: 288-92.

5 Christakis NA, Asch DA. Biases in how physicians choose to withdraw life support. Lancet 1993; 342: 642-6.

6 Walter SD, Cook DJ, Guyatt GH, et al. Confidence in life-support decisions in the intensive care unit: a survey of healthcare workers. Crit Care Med 1998; 26: 44-9.

7 Luce JM, Raffin TA. Withholding and withdrawal of life support from critically ill patients. Chest 1988; 94 : 621-6.

8 Cook DJ, Guyatt GH, Jaeschke R, et al. Determinants in Canadian health care workers of the decision to withdraw life support from the critically ill. JAMA 1995; 273: 703-8.

9 Randolph AG, Zollo $M B$, Wigton RS, Yeh TS. Factors explaining variability among caregivers in the intent to restrict life-support interventions in a pediatric intensive care unit. Crit Care Med 1997; 25: 435-9.

10 Brody H, Campbell ML, Faber-Langendoen K, Ogle KS. Withdrawing intensive life-sustaning treatment Recommendations for compassionate clinical care. $\mathrm{N}$ Engl J Med 1997; 336: 652-7.

11 The Society of Critical Care Medicine Ethics Committee. Attitudes of critical care medicine professionals concerning forgoing life-sustaining treatments. Crit Care Med 1992; 20: 320-6.

12 Rubenfeld $G D$, Crawford SW. Withdrawing life support from mechanically ventilated recipients of bone marrow transplants: a case for evidence-based guidelines. Ann Intern Med 1996; 125: 625-33.

13 Cher DJ, Lenert LA. Method of medicare reimbursement and the rate of potentially ineffective care of critically ill patients. JAMA 1997; 278: 1001-7.

14 Kollef $M H$. Private attending physician status and the withdrawal of life-sustaining interventions in a medical intensive care unit population. Crit Care Med 1996; 24: 968-75.

15 Faber-Langendoen $K$. A multi-institutional study of care given to patients dying in hospitals. Arch Intern Med 1996; 156: 2130-6.

16 Keenan SP, Busche KD, Chen LM, McCarthy L, Inman $K J$, Sibbald WJ. A retrospective review of a large cohort of patients undergoing the process of withhold- ing or withdrawal of life support. Crit Care Med 1997; 25: 1324-31.

17 Smedira NG, Evans BH, Grais LS, et al. Withholding and withdrawal of life support from the critically ill. $\mathrm{N}$ Engl J Med 1990; 322: 309-15.

18 Lee DKP, Swinburne AJ, Fedullo AJ, Wabl GW. Withdrawing care: experience in a medical intensive care unit. JAMA 1994; 271: 1358-61.

19 Wilson WC, Smedira NG, Fink C, McDowell JA, Luce JM. Ordering and administration of sedatives and analgesics during the withholding and withdrawal of life support drom critically ill patients. JAMA 1992; 267: 949-53.

20 Wood GG, Martin E. Withholding and withdrawing life-sustaining therapy in a Canadian intensive care unit. Can J Anaesth 1995; 42: 186-91.

21 Faber-Langendoen K, Bartels DM. Process of forgoing life-sustaining treatment in a university hospital: an empirical study. Crit Care Med 1992; 20: 570-7.

22 Keenan SP, Busche KD, Chen LM, et al. Withdrawal and withholding of life support in the intensive care unit: a comparison of teaching and community hospitals. Crit Care Med 1998; 26: 245-51.

23 Faber-Langendoen $K$. The clinical management of dying patients receiving mechanical ventilation - a survey of physician practice. Chest 1994; 106: 880-8.

24 Ruark JE, Raffin TA, The Stanford University Medical Center Committee on Ethics. Initiating and withdrawing life support. Principles and practice in adult medicine. N Engl J Med 1988; 318: 25-30.

25 Medical Section of the American Lung Association. Withholding and withdrawing life-sustaining therapy. Am Rev Respir Dis 1991; 144: 726-31.

26 American Thoracic Society. Withholding and withdrawing life-sustaining therapy. Ann Intern Med 1991; 115 478-84.

27 American College of Physicians. American College of Phyicians Ethics Manual. Part 2: The physician and society; research, life-sustaining treatment; other issues. Ann Intern Med 1989; 111: 327-35.

28 Bone RC, Rackow EC, Weg JG, Members of the ACCP/SCCM Consensus Panel. Ethical and moral guidelines for the initiation, continuation, and withdrawal of intensive care. Chest 1990; 97: 949-57.

29 Task Force on Ethics of the Society of Critical Care Medicine. Consensus report on the ethics of foregoing life-sustaining treatments in the critically ill. Crit Care Med 1990; 18: 1435-9.

30 Rocker GM, Hall RI, Murray D, Cummings I. Admission and end of life sedation and analgesia preferences in the ICU. Chest 1998; 114: 332S.

31 Hall RI, Rocker GM, Norris J. Care at the end of life Medication use during the final 12 hours in the ICU. Chest 1998; 114: S333. 
Addendum: Readers may find it helpful to obtain the Canadian Critical Care Society Position Paper on Withholding or Withdrawal of Life Support available from the Canadian Critical Care Society by contacting the Society office at 416-340-4623. 


\section{Mortalité à l'USI- l'ex- périence d'Halifax}

Richard I. Hall MD FRCPC FCCP

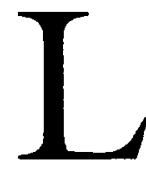

A mortalité à l'unité des soins intensifs (USI) est de plus en plus associée au refus ou à la suppression du traitement ${ }^{1,2}$ et la nature de ces soins a beaucoup retenu l'attention récemment. Un exposé de la situation et des directives ont été présentés par différentes organisations professionnelles au personnel soignant directement concerné par la décision de refuser ou de supprimer les soins. ${ }^{15-29}$

Dans notre établissement, les événements ont tourné au drame quand, le 6 mai 1997, un médecin traitant de l'USI médicaux et chirurgicaux du Queen Elizabeth II Health Sciences Centre (QEII HSC) a été arrêté et accusé de meurtre avec préméditation. Même si le tribunal a rendu une ordonnance de nonlieu dans ce cas, cette situation fait toujours l'objet d'un examen professionnel de la part du Collège des médecins et chirurgiens de la Nouvelle-Écosse, de sorte que nous ne le commenterons pas plus avant. Nous parlerons plutôt de certaines données et observations concernant les soins aux mourants à l'unité des soins intensifs (USI) qui ont été fournies au cours de l'examen subséquent de l'USI réalisé par l'hôpital. Nous commenterons les démarches entreprises par l'hôpital dans les circonstances et exposerons les différences entre les enquêtes criminelles et civiles et les droits des médecins confrontés à de telles questions. Nous voulons aussi faire connaitre au lecteur la variabilité des soins aux mourants à l'USI, sujet qui touche le processus disciplinaire de l'hôpital, et susciter des discussions afin de prévenir d'autres tragédies concernant les soins aux grands malades.

Les soins aux mourants dans une USI de niveau tertiaire Que feraient les médecins et le personnel soignant?30

Pour mieux comprendre notre propre pratique entourant les derniers soins à l'USI, nous avons mis au point au scénario dans lequel un homme âgé atteint d'une maladie pulmonaire sévère a été admis à la suite de la résection intestinale d'urgence, et dont l'état s'est ensuite détérioré au point d'envisager la suppression du maintien artificiel des fonctions vitales. Les médecins devaient indiquer les prescriptions qu'ils allaient écrire pour ce patient placé sous pièce en $T$, et les infirmières recevaient un ensemble de prescriptions et, en s'y référant, elles devaient préciser la quantité de médicaments qu'elles administreraient. Il y a eu des différences de l'ordre de 1 à 10 pour les doses prescrites par les médecins. Les valeurs extrêmes des doses choisies pour la morphine qui pourrait être administrée par les infirmières sont illustrées à la Figure 1. À l'intérieur des contraintes de choix basés sur un unique cas fictif, on note une grande variabilité dans la quantité de médicament qui aurait été administré selon que le médecin et/ou l'infirmière sont au lit du malade au moment où on retire le maintien des fonctions vitales.

\section{Qu'est-ce que les médecins de l'USI font en réalité? 31}

Nous avons réalisé une analyse en profondeur des soins aux mourants à l'USI pendant un an. Pendant cette période, 1327 patients ont été admis à l'USI. Il y a eu 1153 patients vivants à recevoir leur congé de l'USI $(87 \%)$. Chez 138 patients $(10,4 \%)$, des décisions de refuser/supprimer le maintien des fonctions vitales ont été prises et 36 patients de plus $(2,7 \%)$ sont décédés malgré la poursuite du traitement actif. Le décès lié à la suppression ou au refus de traitement s'est donc produit

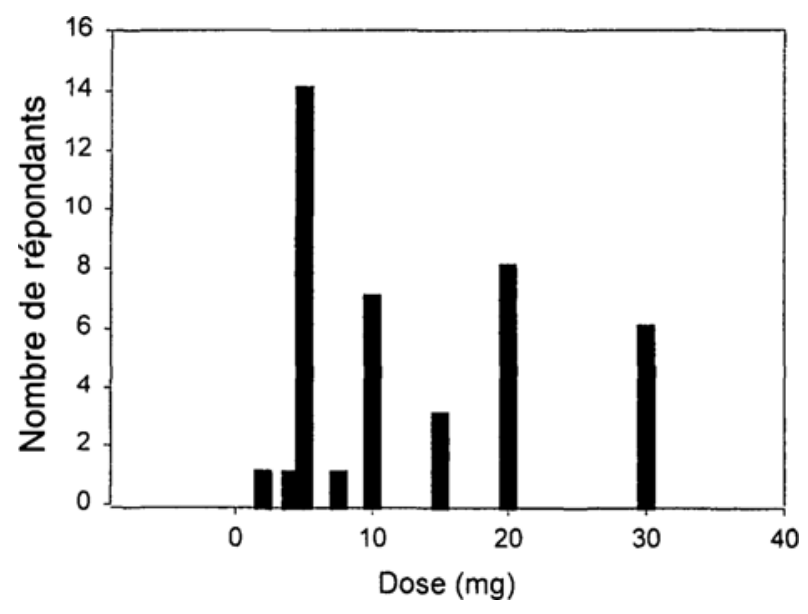

FIGURE 1 Variabilité d'administration de morphine pendant 30 min par des infirmières ayant reçu un ensemble hypothétique de prescriprions impliquant le retrait du maintien des fonctions vitales chez un patient de l'USI. 
chez $79,3 \%$ des non survivants. La dose horaire moyenne de morphine et de lorazépam pendant les 12 dernières heures de vie était 5 fois plus élevée chez les patients à qui on avait retiré le maintien des fonctions vitales que chez ceux à qui on ne l'avait pas retiré. De nouveau, il y avait une grande variabilité entre les médecins quant aux doses de médicaments administrés pour le confort du patient (> 10 fois). D'autres articles sur l'usage de médicaments aux mourants à l'USI rapportent des données semblables aux nôtres. Par exemple, les doses de morphine administrées pendant la suppression du maintien de la vie vont de 0 à $350 \mathrm{mg} \cdot \mathrm{hr}^{-1},{ }^{16,21}$ avec une augmentation de 5,7 $\pm 1,7$ $\mathrm{mg} \cdot \mathrm{hr} \mathrm{r}^{-1}$ avant le retrait à $14,8 \pm 4,5 \mathrm{mg} \cdot \mathrm{hr}^{-1}$ pendant le retrait. ${ }^{19}$ On pourrait se poser raisonnablement la question à savoir pourquoi il y a une si grande variabilité de dosage pendant le retrait du maintien des fonctions vitales.

Les médecins qui offrent des soins palliatifs à l'USI pendant le retrait de l'assistance vitale administrent des doses substantielles de médicaments (habituellement des opioïdes et des sédatifs) afin d'assurer le confort du patient. Cela a été une pratique éthique bien acceptée, basée sur le principe du «double effet». Essentiellement, ce principe permet l'administration de médicaments conçus pour assurer un certain confort au patient pendant ses derniers moments, sachant toutefois que les effets secondaires comme la dépression respiratoire (qui peut hâter la mort causée par sa maladie sous-jacente) sont acceptables, pourvu que l'intention du médecin était de promouvoir le confort du patient. En vertu de ce principe, il n'y a pas de limite supérieure aux doses de médicament et son application pratique peut expliquer certaine variabilité d'usage observée entre les médecins et d'autres soignants auprès des mourants. Par ailleurs, l'expérience nous amène à justifier les changements de médication sur la base de mesures objectives de la douleur, de la dyspnée ou de l'inconfort et à définir les limites supérieures de dosage de médicaments qui seraient révisées régulièrement en fonction de l'évolution de la situation terminale. Les médicaments qui ne produisent pas directement le confort du patient, comme les myorelaxants, sont sans doute problématiques si on les utilise avec des agents pour mettre fin à la «souffrance», peu importe la bonne intention du médecin. Tant et aussi longtemps que les lois canadiennes n'auront pas clarifié la situation, nous ne pouvons recommander une telle pratique. Notre médecin a été accusé de meurtre avec préméditation selon le Code criminel du Canada. L'article 231(2) du Code criminel du Canada ${ }^{a}$ (C.C.C.), en conjonction avec l'a.229 du C.C.C., présente les éléments essentiels de l'accusation de meurtre avec préméditation comme suit :

\section{1. "... où une personne qui cause la mort d'un être bumain \\ i) a l'intention de causer sa mort; ou \\ ii) a l'intention de lui infliger des blessures dont elle sait qu'elles pourraient causer la mort, et est sans remords si la mort s'ensuit ou non; $\aleph^{b}$}

2. Et que le meurtre a été "prémédité et délibéré»."

Selon l'interprétation de chacun, presque tous les cas de retrait du maintien des fonctions vitales pourraient être remis en question en regard des médicaments employés. Pour cette raison, il est essentiel que les médecins enregistrent les conversations qu'ils ont eues avec le patient et sa famille et qu'ils documentent leur intention et agissent avec précaution.

Nous allons maintenant aborder les conséquences d'une telle responsabilité sur les individus et les institutions.

\section{Evénements exceptionnels et attitudes professionnelles} Cela pourrait en surprendre plusieurs qu'un médecin qui constate le décès d'un patient dans des circonstances inhabituelles ne soit pas tenu de rapporter le cas, dans certaines provinces y compris la NouvelleÉcosse, à des autorités à l'extérieur de l'hôpital. L'Alberta, à l'a.10 du Fatality Inquiries Act exige la déclaration immédiate à un médecin légiste ou à un enquêteur par toute personne ayant connaissance ou une raison de croire qu'une personne est décédée dans des circonstances qui incluent, entre autres, un «décès inexpliqué", un "décès qui serait survenu à la suite de traitement inapproprié ou négligent"; un décès pendant ou peu de temps après une intervention chirurgicale et un décès après empoisonnement. La Colombie Britannique, dans son Coroner's Act, ${ }^{e}$ formule une exigence similaire de rapporter au médecin légiste ou à un agent de la paix les "faits et circonstances relatifs à la mort» par toute personne qui a des raisons de croire que la mort est le résultat, entre autres, de "négligence, mauvaise conduite, faute professionnelle» ou toute cause autre que la maladie, dans des circonstances qui peuvent nécessiter une enquête. (voir a.9) ${ }^{\mathrm{f}}$ Le Coroners' Act du Nouveau-Brunswick, à

\footnotetext{
a Criminal Code of Canada R.S.C. 1985, c.C-46, tel qu'amendé

b s.229(a) (i); 229(a)ii) Criminal Code of Canada

c s.23l (2) C.C.C.

dR.S.A. 1980, c.F-6, tel qu'amendé

'R.S.B.C. 1996, C.72, tel qu'amendé

f R.S.N.B. c.C-23, tel qu'amendé
} 
l'a.4, a une disposition semblable à celle de la Colombie Britannique.

$\mathrm{Au}$ QEII HSC, à la suite de l'investigation qui a eu lieu à l'intérieur de l'hôpital, les privilèges de médecins ont été modifiés, mais l'hôpital n'a pas rapporté le cas à la famille, au Comité consultatif médical, au Conseil d'administration, au médecin légiste ou au Collège des médecins et chirurgiens de la Nouvelle-Écosse. Dans le rapport subséquent du groupe d'examen externe présidé par le docteur Charles Wright, on a déclaré que "les démarches entreprises, aussi inappropriées qu'elles aient pu l'être, l'ont été dans une tentative malencontreuse de protéger un collègue de conséquences possiblement graves résultant d'un acte de compassion apparent et de protéger l'bôpital d'une publicité défavorable». Les enquêteurs de la police ont apparemment conclu, qu'à cause de la non- divulgation, l'hôpital et son personnel étaient activement engagés dans une tentative d'étouffer l'affaire nécessitant, dans leur esprit, une perquisition minutieuse et à l'improviste. Le rapport Wright a recommandé qu' «Au-delà des contraintes de confidentialité avec le patient et de renseignements sur la vie privée protégés par la loi, la divulgation complète d'événements extraordinaires et de démarches institutionnelles soient faites dans le meilleur intérêt de l'institution et du public». On peut se demander si l'atmosphère chargée, en l'absence de discussion libre, a pu contribuer à l'accusation qui était beaucoụp plus sérieuse que celle qui avait été portée dans des circonstances similaires, par ex. l'administration d'une substance dangereuse contraire à l'article 245 du C.C.C. Dans notre propre cas, les dommages causés aux personnes impliquées dans cette affaire, à leur réputation, incluant celle de l'institution et de ses dirigeants, la perte de confiance du public envers l'hôpital et sa capacité à assurer les soins à sa clientèle, les dommages moraux au personnel soignant de l'USI, le coût de l'enquête réalisée dans le but de découvrir les erreurs, et qui les avait commises, et la mise au point du processus rectificatif ont été énormes. Nous recommandons que les institutions et leurs dirigeants envisagent avec soin les effets de leurs décisions prises dans le but de servir les meilleurs intérêts des individus ou de l'institution vue comme une entité.

À la suite de son examen sur la façon dont l'hôpital avait pris la situation en main, le Comité du docteur Wright a fait certaines recommandations comprenant la divulgation d'événements extraordinaires, des amendements au Medical Act de Nouvelle-Écosse afin d'exiger une déclaration obligatoire de situations où les privilèges d'un médecin sont révoqués pour plus de deux semaines, un changement au Fatality Inquiries Act afin de rendre obligatoire le signalement au médecin légiste de toute mort suspecte ou inhabituelle, des changements aux statuts de l'hôpital afin de mentionner les circonstances inhabituelles et des efforts pour informer le public et les personnes impliquées dans les soins aux mourants.

Les efforts se poursuivent actuellement pour assurer la divulgation complète des événements inhabituels, les statuts de l'hôpital sont en révision et la formation public/professionnel est en marche. Des lettres ont été envoyées au nom du QEII HSC aux autorités compétentes afin de requérir l'amendement statutaire. Cependant, aucune modification de la loi n'a été annoncée. Une meilleure définition des soins acceptables pour les malades en phase terminale est exigée ainsi qu'une distinction entre les actes de compassion et les actes de malveillance. On demande également de fournir des indications sur l'à-propos et la nature de toute déclaration nécessaire et de la personne à qui on doit les faire.

\section{Questions juridiques}

L'expérience des événements qui se sont produits au QEII HSC nous fait mieux comprendre le processus juridique, bien que dans des circonstances que nous n'avions pas choisies. Afin de renseigner d'autres médecins qui pourraient sans le vouloir se trouver impliqués dans des événements malheureux aux conséquences légales, ce qui suit aborde quelques aspects de la loi avec lesquels nous croyons que les médecins devraient se familiariser.

Les différences entre les poursuites au civil et au criminel Les différences majeures concernent la nature des parties en cause et le but des procédures. Les procès civils sont des actions privées entreprises par une partie, le demandeur, contre une autre partie, le défendeur, dans le but d'obtenir réparation pour un préjudice présumé ou un méfait dans l'intention de récupérer les frais encourus résultant de l'offense perçue. En soi, la preuve déposée devant le tribunal concerne la responsabilité du défendeur et le montant des dommages qui en découlent. Quoiqu'on puisse obliger la production de documents utiles et possiblement exiger d'être présent pour témoigner à l'audition de la cause, il y certaines restrictions quant à l'accès aux documents des parties opposées et à leurs conseillers, aussi bien qu'à ceux de tierces parties qui ne sont pas présentes dans un procès criminel.

Selon la loi criminelle, lorsque les enquêteurs de la police sont mis au courant de méfaits possibles, ils ont l'obligation de mener une enquête approfondie et, si à la fin de cette investigation ils ont des motifs raisonnables et valables de conclure qu'une offense a été 


\section{Queen Elizabeth II Health Sciences Centre}

\section{RETRAIT DU MANTIIEN DES FONCTIONS VITALES : RECAPITULATION}

1. Le patient a- $t$-il un testament valide ou une procuration permanente pour les questions de santé?

Si OUI, est- ce que la décision proposée du retrait du maintien des fonctions vitales répond aux souhaits du testament ou de la procuration permanente? vitales répond aux

2. Le médecin référant a-t-il été mis au courant? Service

3. Opinion du deuxième médecin traitant sur le retrait de l'assistance vitale?

4. Si le patient est apte à pendre une décision, a-t-il pris part à la discussion préalable?

5. Si le patient est inapte ou inconscient, a-t-on impliqué le parent le plus proche ou le substitut dans la prise de décision?

6. Le médecin de l'USI a-t-il fourni le plan de soins à la famille?

Si NON, pourquoi? Ex. : impossible à joindre

7. La discussion est-elle rapportée au dossier par :

\section{LE MEDECIN} L'INFIRMIÈRE

8. La prescription NE PAS RÉANIMER a-t-elle été écrite?

9. Le patient et/ou sa famille ont-ils pu parler à un guide spirituel?

10. Y a-t-il des pratiques religieuses/culturelles particulières à respecter lors du décès? Énumérer

11. S'il y a lieu, d'autres conseillers ont-ils été prévenus? Service

12. Les MESURES DE CONFORT sont- elles assurées?

13. Est-ce que tout autre traitement actif a été supprimé?

Oui

Non

Oui

Quand

O Oui

refusé

Oui

Non

$\square$ Oui

$\square$ Non requis

$\square$ Oui

口 Oui
SIGNATURE DU MÉDECIN
SIGNATURE DE L'INFIRMIÈRE

\section{DATE}

J/MM/AAAA

FIGURE 2

commise, de porter alors une accusation (appelée une dénonciation) devant le tribunal approprié de juridiction criminelle. Pendant cette investigation, la police a des pouvoirs étendus de perquisition et de saisie qui doivent être généralement pré-autorisés par un juge de paix ou un juge émettant un mandat de perquisition.

Le fonctionnement de l'hôpital, y compris les activités examinées par les pairs et les dossiers privés, qui peuvent être exempts d'une fouille minutieuse dans la poursuite civile, sont susceptibles de saisie et d'examen par les enquêteurs de la police lors d'une poursuite criminelle. Ces documents peuvent être rendus publics ultérieurement. Il n'y a plus de droit de tenir une information secrète entre le médecin et son patient dans les cas criminels. Dans ce cas également, le secret entre un avocat et son client est l'un des quelques faits reconnus qui permettent de garder les documents saisis à l'abri des indiscrétions du public. La loi n'est pas claire sur le secret lors de la révision par les pairs.

Une fois que des accusations sont portées, l'avocat de la Couronne doit examiner les informations déposées et déterminer si oui ou non la poursuite con- 
tinue sur la base de ces motifs, ou d'autres motifs ou sur l'ensemble. Les provinces disposent de différents tests que les avocats de la Couronne doivent appliquer pour déterminer si on doit aller de l'avant avec les actions intentées par la police.

\section{Vos droits et ce que vous pouvez faire, confrontés à une enquête criminelle}

Lors d'une enquête criminelle, vous pouvez être interrogé par la police. D'après mon expérience personnelle, ce peut être très intimidant. Le premier contact avec la police lors de l'enquête d'Halifax s'est produit quand les policiers ont pénétré dans les bureaux des médecins des soins intensifs pour examiner tous les dossiers personnels, les fichiers informatisés, etc. La police était bien informée, savait quelles questions poser et où chercher les documents pertinents. Cette fouille a été suivie de l'interrogatoire de chacun des médecins concernant leur rôle dans l'affaire. Aucune information n'a été donnée sur le droit à la représentation juridique et les «déclarations» ont été enregistrées sans qu'un avocat soit présent auprès de médecins qui n'avaient pas insisté sur la présence d'un conseiller juridique. Aucune possibilité d'entrer en contact avec un avocat n'a été accordée, mais l'impression a été donnée plutôt que, à moins d'une coopération totale, les médecins pouvaient être considérés comme des complices au «crime». Avec le recul, la leçon à tirer est que la présence d'un avocat assure votre protection et que vous ne devriez pas faire de déclaration, même si vous n'avez rien à cacher, sans un avis juridique, si intimidante qu'apparaisse la discussion sur le sujet. Sans cet avis, vous pouvez faire des déclarations sous la contrainte que vous regretterez plus tard.

Quand vous entrez en contact pour la première fois avec la police, il est important de déterminer si elle souhaite parler avec vous en qualité de témoin ou de suspect. Dans les deux cas, vous devriez demander de consulter un conseiller juridique avant de fournir une déclaration ou de participer à une entrevue. Si vous êtes suspect, vous avez un droit absolu de consulter un conseiller et devriez le faire avant de dire quoi que ce soit à la police. Si vous êtes témoin, la police n'a pas l'obligation de vous aviser que vous pouvez parler à un conseiller avant d'être interrogé. En général, le témoin n'est pas obligé de parler à la police. Refuser de répondre aux questions jusqu'à ce qu'il soit possible de consulter quelqu'un serait tout à fait légitime et indiqué.

$\mathrm{Si}$ la police arrive à votre bureau avec un mandat de perquisition, elle doit vous en donner une copie qui doit préciser la date, l'heure, l'endroit et l'objet de la fouille. Le mandat doit être attentivement examiné sous cet angle. Si les policiers ne vous donnent pas une copie du mandat de perquisition, vous pouvez en demander une. S'ils ont un mandat, alors ils ont le droit de fouiller votre bureau et de saisir tout le matériel mentionné par le mandat. S'ils n'ont pas de mandat, alors ils n'ont pas le droit de fouiller votre bureau et vous pourriez briser le secret professionnel si vous acceptiez une telle perquisition en l'absence d'un mandat. Sans un mandat de perquisition, vous pouvez leur demander de partir. Votre objection étant clairement formulée, si les policiers refusent de quitter la pièce, leur conduite peut faire l'objet d'un examen judiciaire et/ou disciplinaire à la suite d'une plainte de votre part.

Si vous êtes cité à comparaître au tribunal, vous devriez consulter un conseiller pour vous assurer que l'assignation est valide et que vous avez des preuves utiles à fournir. Il y a une modalité par laquelle votre avocat, dans certaines circonstances, peut faire annuler la citation. Autrement, vous devez vous présenter au tribunal comme c'est exigé.

\section{Démarches entreprises à la suite de cette expérience}

Nous avons examiné nos façons de procéder avec les mourants de l'USI. Nous avons révisé, en particulier, les dispositions entourant la sédation et l'analgésie en général aux patients de l'USI et nous avons mis au point un algorithme de sédation basé sur l'évidence scientifique pour régir cet aspect des soins. Nous avons adopté un outil d'évaluation de la douleur/sédation/dyspnée qui nous permette d'identifier et, en conséquence, de traiter efficacement les complications. Nous avons abandonné l'usage des "ordonnances permanentes" pour la sédation et l'analgésie pendant le retrait du maintien des fonctions vitales. Nous exigeons que les médecins traitants expliquent davantage la situation aux familles et soient plus attentifs aux soins des mourants. Nous avons mis en place une liste de récapitulation sur le refus du maintien des fonctions vitales afin de nous assurer que nous n'allons plus négliger, laisser passer ou aborder de façon inadéquate les sujets mentionnés dans nos enquêtes sur les besoins des patients à satisfaire, par ex. : les besoins religieux ou spirituels (Figure 2). Nous avons nommé un médecin des soins palliatifs membre honoraire de notre groupe de l'USI et nous tentons d'établir une meilleure interaction entre les soins palliatifs et les soins intensifs. Nous sommes à mettre au point une liste de choses à faire concernant la prescription «Ne pas réanimer" (NPR). Ces mesures nous ont permis d'apporter des améliorations aux standards de soins et à la documentation sur la période de retrait du maintien des fonctions vitales. 


\section{Conclusion}

Dans l'optique de la démarche, soyez attentif à ce qui se dit pendant les procédures d'actions disciplinaires et à ce qui s'écrit sur le sujet par la suite. On devrait examiner soigneusement l'exactitude du procès-verbal de telles réunions et le faire corriger si nécessaire. Il est toujours bon de penser comment la documentation serait présentée à la une du journal national ou diffusée à la radio ou à la télévision. Dans tout procès criminel, il est vraisemblable que des documents utilisés en preuve soient ensuite rendus publics. À propos des soins aux mourants à l'USI, il y a un réel besoin de dialogue. Les médecins gagneraient à s'informer sur ce genre de soins et à s'engager à faire connaître le sujet au public. Étant donné la variabilité des soins qu'on a pu observer pendant la période où l'assistance des fonctions vitales a été suspendue, l'admission à l'hôpital d'une population de patients plus âgés et plus malades et le manque de dialogue approprié aux niveaux fédéral et provincial sur la modification des statuts actuels, la possibilité de futures actions en justice (autant civile que criminelle) est malheureusement très réelle. Nous croyons qu'il est temps qu'une organisation professionnelle comme la Société des anesthésiologistes canadiens (SAC) s'occupe davantage de cette question d'un point de vue formatif et politique.

Addenda : Les lecteurs qui veulent obtenir la Déclaration de principe de la Société canadienne des soins intensifs sur le refus ou le retrait du maintien des fonctions vitales, offerte au bureau de la Société canadienne des soins intensifs, peuvent téléphoner au 416-340-4623.

\section{Références}

(Voir page R61) 